and by extending the body and again bringing up the pleon to its reflexed position to push its way along the tube.*

The tube (see fig. A) is cylindrical, of the same diameter throughout except at each end where it is somewhat widened ; the two ends are quite similar and appear to be equally and indifferently used by the animal. The tube is quite free and unattached and is no doubt carried about by the animal when it moves. The material of which it is made is fairly tough, the surface is smooth and the whole appears to be formed from the secretion produced by the glands in the first and second pereiopoda, no sand grains being used as in Cerapus sismithi.

The tubes that I have seen are all of the same shape, but they very much in size, the largest being about $\cdot 46$ inches long and $\cdot 03$ inches in diameter, others being of only half these dimensions. Many of the tubes and especially of the smaller ones were empty and I presume that when the animal has grown too large for its tube it leaves it and secretes another and larger one.

From the description which has now been given of the male of this species it appears that $C$. Alindersi is not very different from C. sismithi described by Stebbing from Kerguelen Island; it differs from that species however in the antennæ, to some extent in the second gnathopoda and also in the armature of the uropoda.

\title{
DESCRIPTIONS OF THREE NEW AUSTRALIAN LIZARDS.
}

By J. Douglas Ogilby.

\section{Gymnodactylus sphyrurus, $s p$. nov.}

Head rather large ; a strong transverse ridge crosses the occiput immediately behind the eyes, ending on either side in a blunt point placed at the postero-superior angle of the orbit; from this runs forward an inwardly curved, elevated, supraciliary ridge which is continued on the snout by a conversely curved angular canthus rostralis; these ridges form the margin on the forehead of an oval, and between the orbits of a subtriangular, depression; loreal region concave; the length of the snout is one and two-fifths

* Some very interesting remarks on Cerapus abditus were given many years ago by Templeton, see Stebbing's " Report on the 'Challenger" Amphipoda," p. 168. 
of the diameter of the eye, and the distance between the eye and the ear-opening is equal to that between the eye and a point midway between the nostril and the tip of the snout. Interorbital space broad, broader in comparison than in G. platurus or $G$. cornutus. Ear-opening a narrow vertical slit, about one third of the diameter of the eye. Body short and rather compressed, barely two and a third times the length of the head. Limbs long; digits rather short and thick, subcylindrical at the base, and but little compressed on the distal phalanges. Head covered with small granules intermixed with rounded tubercles, which are largest near the end of the snout; outer margin of the upper eyelid with two strong ridges upon which small tubercles predominate; two slight longitudinal folds on the sides of the neck and a vertical fold in front of the forelimb, all of which are more thickly studded with tubercles than are the surrounding parts; rostral hexagonal twice as broad as high, without any indication of median groove above ; nostril directed posteriorly, bordered in front by a large nasal, which is larger than the first upper labial, and separated from the latter by a series of small granules; labials small, thirteen or fourteen upper and eleven lower; mental trapezoidal, bordered posteriorly by five small granules; body above covered by minute granules, intermixed with rounded and conical tubercles; limbs similarly protected, but with the granules larger and the tubercles smaller; below with flat subimbricate granules; no lateral fold. Tail short, broad, and thick, depressed, malleiform, not contracted at the base, from which the enlarged portion expands at right angles; the expanded portion is formed of six broad transverse ridges, and is quadrilateral ; its length is three-fourths of its breadth, which is one-sixth more than that of the body at its broadest part ; it ends almost as abruptly as it commences, and terminates in an attenuated point, which rises from the postero-inferior margin of the swollen portion, and is barely four-sevenths of its length; the tail is covered above by minute granules anteriorly and much larger flattened subimbricate granules posteriorly ; on the former portion there are four regular transverse series of strong conical tubercles, on the latter a single series on each side near the margin; sides with an upper series of very strong conical tubercles, and a lower series of weaker ones; below with subimbricate granules; attenuated portion covered with small rounded granules.

Colors.-Head and neck above brown with darker and lighter marbling and most of the tubercles yellow; the sides pale yellowishbrown with irregular blackish bands, which are vertical on the former and horizontal on the latter; back brown with narrow yellowish transverse bands, mainly caused by the prevalence of that color on the tubercles; sides and limbs light brown streaked and marbled with darker brown; under surface dirty yellowish- 
brown; tail above dark brown, the expanded portion with two broad light colored cross-bands ; the anterior near its commencement, the posterior marking its termination; below dark brown densely spotted with yellow; the attenuated portion with two annular yellow rings.

\begin{tabular}{lllll}
\multicolumn{4}{c}{ Dimensions. } \\
Total length & $\ldots$ & $\ldots$ & 89 & millim. \\
Length of head $\ldots$ & $\ldots$ & 18 &, \\
Width of head $\ldots$ & $\ldots$ & 13 &, \\
Length of body ... & $\ldots$ & 42 & $"$ \\
Length of fore limb & $\ldots$ & 24 &, \\
Length of hind limb & $\ldots$ & 30 &, \\
Length of tail $\ldots$ & $\ldots$ & 29 &,
\end{tabular}

Habitat.-Interior of New South Wales (Tumut?).

Type.-In the Australian Museum, Sydney.

The unique example described above forms one of a small collection lately forwarded to the Museum. The bottle which contained it is labelled "Tumut," but as the remaining bottles are unlabelled, and no information as to the sender is procurable, some doubt as to the true locality necessarily remains.

This species differs greatly from the other broad-tailed forms of Gymnodactylus, but is more closely allied to G. miliusii, than to platurus or cornutus.

\section{Gymnodactrlus cornutus, $s p$. nov.}

Head large, the snout depressed, the occiput raised above the level of the eye and forming with the snout a moderately convex surface the apical point of which is on a line with the posterior margin of the orbit; the length of the snout is one and threefourths of the diameter of the eye; the distance between the eye and the nostril is greater than that between the eye and the earopening. Forehead and loreal region slightly concave; supraciliary region so much enlarged and elevated as to leave only a deep narrow fossa between the orbits. Ear-opening elongatepyriform, vertical, five-eighths of the diameter of the eye. Body moderately elongate and attenuated, more than three and a half times the length of the head. Limbs long; digits strong, subcylindrical at the base, the distal portion strongly compressed and elevated; claws very strong. Head covered with small granules intermixed with conical or rounded tubercles; granules of the upper eyelid rather larger than those of the head, the tubercles numerous and rounded; a strong spinate knob, surmounted by a conical tubercle behind the eye ; ear-opening protected in front and above by a tuberculated ridge; rostral subquadrangular, three times as broad as high, almost completely divided by a shallow median groove; nostril directed posteriorly, in contact 
with the rostral and first labial ; labials small, fifteen upper and thirteen lower; mental trapezoidal, bordered posteriorly by five enlarged granules. An arcuate row of six strong conical tubercles, each of which is encircled by smaller tubercles, on the nuchal region; body and limbs above covered with small granules, intermixed with rounded, conical, and spinose tubercles; below with flat granules; the two separated by a very distinct flap, the outer margin of which is ornamented with a series of triangular dermal appendages, each of which is provided with a similar smaller appendage in front and behind. Tail of moderate length, depressed, broad, leaf-like, strongly contracted at the base, and attenuated at the tip, covered above by minute granular scales, intermixed, except on a vertebral patch of the leaf-like expansion, with soft triangular appendages.

Colors.-Chestnut- or blackish-brown above, with five large angular whitish spots, undulated or marbled with brown, the first and smallest on the nuchal region, the fifth between the hind limbs; a whitish band from behind the eye to the ear-opening, and another along the side of the neck immediately in front of the fore limb ; labials white, marbled with dark brown; limbs above with indications of lighter cross-bars; tail with three broad whitish transverse bands above; below white, uniform or minutely spotted with brown.

\section{Dimensions.}

$\begin{array}{lcccc}\text { Total length } & \ldots & \ldots & 210 & \text { millim. } \\ \text { Length of head } & \ldots & \ldots & 37 & , \\ \text { Width of head } & \ldots & \ldots & 31 & , \\ \text { Length of body } \ldots & \ldots & 90 & , \\ \text { Length of fore limb } & \ldots & 66 & , \\ \text { Length of hind limb } & \ldots & 72 & , \\ \text { Length of tail ... } & \ldots & 83\end{array}$

Habitat.-Bellenden-Ker Ranges, North-eastern Queensland.

Type.-In the Australian Museum, Sydney.

The first examples of this fine Gecko which came under my notice formed part of a collection obtained by Messrs. Cairn and Grant during the àutumn of 1889 in the locality indicated above; these were determined, on a cursory examination, as "Gymnodactylus platurus, northern form" (vide Rec. Austr. Mus. i. p. 30). A fine example since forwarded, with other material, to the Museum by Mr. Day, coupled with the fact that at the time of its arrival I was engaged on a revision of the Australian Geckos, induced me to pay more attention to this form, with the result that I find it to be very distinct from $G$. platurus, its nearest ally, with which it has evidently been confounded, and which also ranges at least as far northwards as the Bellenden-Ker one of the 
specimens collected by Messrs. Cairn and Grant being specifically inseparable from the southern Leaf-tailed Gecko.

Five out of the six specimens available for examination had reproduced tails, that of the remaining example being as described above; whether this lepidosis is normal or abnormal is, under the circumstances, rather a difficult question to decide, but the fact that I have before me an example of Gymnodactylus platurus which though fully adult and with a longer and more attenuated tail than prevails in the ordinary run of specimens, has this vertebral patch as fully developed as in the specimen described; it seems, therefore, probable that this locally unarmed patch may or may not be present in individuals of the same species, since other undoubted specimens of $G$. platurus show little or no sign of it.

\section{Diplodactylus intermedius, $s p$. nov.}

Head oviform, convex; snout rounded, much longer than the distance between the eye and the ear-opening, from once and threefourths to twice the diameter of the orbit; eye large ; ear-opening of moderate size, round Body and limbs rather strong. Digits depressed, with large transverse lamellæ inferiorly, seven or eight under the fourth toe, the two or three anterior subcordiform, the middle two transversely oblong, and the hasal ones divided into two subcircular plates; the plates under the apex of the digits large, together cordiform. Upper surfaces coverd with moderatesized, juxtaposed, round or oval granules, distinctly smaller on the nuchal region intermixed on the back with large conical tubercles, forming two regular longitudinal series, which extend a short distance along the tail. Rostral subquadrangular, completely divided mesially; nostril pierced between the rostral, first labial, and three nasals, the anterior of which is much the larger, and is separated from its fellow by a transverse oval granule, which is rarely split in two; eleven to thirteen upper and ten to twelve lower labials; mental small, triangular or trapezoidal, not or but little larger than the adjacent labials; no regular chin-shields. Lower surfaces covered with small juxtaposed granules largest on the chin, smallest on the throat. Males with a curved series of preanal pores, five or six on each side, interrupted in the middle, and with from two to four large granules on each side of the base of the tail. Tail short, subcylindrical, covered with small granules; seventeen more or less regular transverse bands of strong tubercles, the anterior band connecting the terminal points of the dorsal and basi-caudal longitudinal series.

Colors.-Upper surfaces bluish-gray, with irregular lines and patches of black scales; all the tubercles yellow; lower surfaces gray, closely dotted with black or brown, each dot representing a granule. 


\begin{tabular}{lcccc}
\multicolumn{5}{c}{ Dimensions. } \\
Total length & $\ldots$ & $\ldots$ & 100 millim. \\
Length of head & $\ldots$ & $\ldots$ & 16 &, \\
Width of head & $\ldots$ & $\ldots$ & $11 \cdot 5$ &, \\
Body .. & $\ldots$ & $\ldots$ & 47 &, \\
Fore limb... & $\ldots$ & $\ldots$ & $22 \cdot 5$ &, \\
Hind limb & $\ldots$ & $\ldots$ & 27 &, \\
Tail ... & $\ldots$ & $\ldots$ & 37 &,
\end{tabular}

Habitat.-Interior of New South Wales.

The species here described belongs to the tuberculated section of the genus, but differs in several constant characters from each of the three described forms belonging to that section; from ciliaris it is manifestly different in the absence of spinous tubercles on the supraciliary region, while from strophurus it is equally well distinguished by the presence of tubercles on the tail ; its nearest ally, therefore, is spinigerus, whose place it would appear to take in the interior of this Colony ; from that species, however, it differs in the following, among other, characters:-The snout is very much longer; the dorsal tubercles form two regular longitudinal series; there are eleven to thirteen upper and ten to twelve lower labials only; and the tail is armed with transverse rows of strong tubercles; while in spinigerus the snout is only a little longer than the diameter of the orbit, the tubercles are irregularly scattered over the dorsal surface, there are thirteen to fifteen upper, and as many lower labials, and the caudal tubercles are arranged in a single longitudinal series on each side of the tail and are black.

SUPPLEMENT To THE DESCRIPTIVE CATALOGUE OF "NESTS AND EGGS of BIRDS FUUND BREEDING IN AUSTRALTA AND TASMANIA."

[Part II., April 1892.]

By A. J. North, F.L.S.

Since the issue of Part I. the following new nests and eggs have been obtained and are herein described :-Eidoliisoma tenuirostre, Turnix melanotus, Ptilotis frenata, and Polytelis alexandra. Descriptions of nests and eggs also appear that are not given in the Catalogue, as well as additional information on the nidification of other species. I here express my indebtedness to the col- 


\section{$2 \mathrm{BHL}$ Biodiversity Heritage Library}

Ogilby, J. Douglas. 1892. "Descriptions of three new Australian lizards." Records of the Australian Museum 2, 6-11. https://doi.org/10.3853/j.0067-1975.2.1892.1180.

View This Item Online: https://www.biodiversitylibrary.org/item/31634 DOI: https://doi.org/10.3853/j.0067-1975.2.1892.1180

Permalink: https://www.biodiversitylibrary.org/partpdf/4603

\section{Holding Institution}

Harvard University, Museum of Comparative Zoology, Ernst Mayr Library

\section{Sponsored by}

Harvard University, Museum of Comparative Zoology, Ernst Mayr Library

\section{Copyright \& Reuse}

Copyright Status: NOT_IN_COPYRIGHT

This document was created from content at the Biodiversity Heritage Library, the world's largest open access digital library for biodiversity literature and archives. Visit BHL at https://www.biodiversitylibrary.org. 